\title{
Perancangan Sistem Pendukung Keputusan Diagnosa Penyakit pasca Lebaran dengan Metode Forward Chaining
}

\author{
Adhie Tri Wahyudi ${ }^{* 1}$, Donny Wahyu Widodo ${ }^{* 2}$ \\ ${ }^{1,2}$ Program Studi Teknik Industri, Fakultas Teknik, Universitas Setia Budi \\ Jln. Letjen. Sutoyo, Mojosongo, Surakarta 57127 \\ Email: ${ }^{* 1}$ adhie@ setiabudi.ac.id, ${ }^{* 2}$ wahyudonny22@ gmail.com
}

\begin{abstract}
Abstrak
Perubahan pola konsumsi makan yang tiba-tiba pada hari raya lebaran, dengan kandungan dominan santan, lemak dan manis dapat memicu datangnya penyakit. Terlebih, jika kemudian makanan tersebut dimasak berulang-ulang, maka lemak jenuhnya semakin tinggi. RSUD Dr. Soetomo, Surabaya melaporkan bahwa pasien dengan penyakit akibat perubahan pola makan lebih mendominasi dibandingkan pasien darurat akibat kecelakaan. Cukup tingginya potensi munculnya penyakit akibat perubahan pola makan saat hari raya Idul Fitri menunjukkan bahwa diperlukan sebuah metode diagnosa yang tepat untuk deteksi dini. Aplikasi Sistem Pendukung Keputusan (SPK) dapat digunakan sebagai alat bantu bantu pengambil keputusan diagnosa penyakit pasca Lebaran yang menjadi topik penelitian ini. Penelitian ini memiliki tujuan melakukan perancangan aplikasi SPK yang mengadopsi kepakaran dari seorang dokter, yang mampu men-diagnosa penyakit pasca Lebaran. Metode inferensi forward chaining digunakan untuk menghasilkan keputusan berdasarkan input yang diberikan user. Berdasarkan hasil analisis, perancangan dan hasil ujicoba yang telah dilakukan maka Sistem Pendukung Keputusan yang dibangun telah berhasil membantu user melakukan self diagnosis terhadap gejala penyakit yang mungkin diderita pada pasca lebaran.
\end{abstract}

Kata kunci : Sistem Pendukung Keputusan, SPK, DSS, Diagnosa Penyakit, Penyakit pasca Lebaran, Forward Chaining

\section{PENDAHULUAN}

Sistem Pendukung Keputusan (SPK) merupakan pendekatan atau metodologi untuk mendukung keputusan yang dapat memasukkan suatu komponen pengetahuan (Moore dan Chang, 1980 dalam Tariq dan Rafi, 2012). Sedangkan Bonczek (1980) dalam Yunus dan Setyowibowo (2011) menyebutkan bahwa SPK (Decision Support Systems) adalah sebuah system yang dibangun dengan komponen sistem bahasa (language), system pengetahuan (knowledge) dan sistem pemrosesan masalah (problem processing) yang saling berinteraksi satu dengan yang lainnya. Indraswari, Soebroto dan Marhaendraputro (2015) Wahyudi, dkk. (2017) menyebutkan bahwa aplikasi SPK dapat memberikan proses pemilihan alternatif tindakan untuk mencapai tujuan tertentu. Berdasarkan definisi SPK yang telah dijelaskan pada penelitianpenelitian terdahulu, SPK dapat digunakan sebagai alat bantu bantu pengambil keputusan diagnosa penyakit pasca Lebaran yang menjadi topik penelitian ini.

Yuwono (2013) mengatakan bahwa proses diagnosa terhadap gejala penyakit membutuhkan peran seorang expert atau pakar, tidak dapat dilakukan oleh sembarang orang. Oleh karena itu, penelitian ini memiliki tujuan merancang sebuah 
aplikasi SPK yang mampu men-diagnosa penyakit pasca Lebaran. Aplikasi SPK ini dibangun dengan komponen system pengetahuan (knowledge) yang mengadopsi kepakaran dari seorang dokter. Sehingga diharapkan, user (pengguna aplikasi SPK) yang merupakan orang awam mampu melakukan analisa data gejala yang dirasakan dan sistem membantu memberikan kesimpulan berupa deteksi dini jenis penyakit mungkin diderita.

Hari Raya Idul Fitri biasanya dirayakan dengan banyak hidangan makanan nan lezat. Di Indonesia, Makanan dan minuman yang disediakan saat Lebaran, menurut dia, sebagian besar berlemak tinggi, manis dan asin. Apalagi, jika makanan tersebut dimasak berulang-ulang, maka lemak jenuhnya semakin tinggi. Begitu juga dengan kue-kue dan minuman kaleng maupun bersoda dengan kandungan gula yang tinggi.

Pada hari itu, biasanya kita sering memanjakan diri dengan memakan segala hidangan yang disediakan. Padahal, sebelumnya perut kita telah terbiasa dengan porsi makan yang sedikit ketika menjalani rutinitas puasa. Perubahan pola konsumsi makan yang tiba-tiba dengan kandungan dominan santan, lemak dan manis dapat memicu datangnya penyakit. Januwati (2016) dalam reportase online bersama dokter penyakit dalam Rumah Sakit Cipto Mangunkusumo (RSCM) Jakarta, Ari F. Syam, menyebutkan bahwa seseorang dengan riwayat penyakit kencing manis akan cenderung gula darahnya menjadi tidak terkontrol setelah banyak makan makanan berlemak dan manis. Fitriani (2012) juga menyebutkan bahwa seseorang dengan penyakit darah tinggi, hiperkolesterol atau asam urat tinggi, ketika mengkonsumsi makanan dengan kadar lemak tinggi dalam jumlah yang banyak maka keadaan tekanan darah, kolesterol dan asam uratnya berpotensi menjadi bertambah parah.

Oleh karena itu, pada hari raya Idul Fitri patut diwaspadai ancaman penyakit kronis yang mengintai pasca-Lebaran terkait dengan pola makan. Sofiana (2016) dalam laporan wawancaranya, menyebutkan bahwa pada saat lebaran dan beberapa hari pasca lebaran, RSUD Dr. Soetomo, Surabaya, mengalami peningkatan pasien yang berobat dari perubahan pola makan. Disebutkan pula bahwa pasien dengan penyakit akibat perubahan pola makan lebih mendominasi dibandingkan pasien darurat akibat kecelakaan. Cukup tingginya potensi munculnya penyakit akibat perubahan pola makan saat hari raya Idul Fitri menunjukkan bahwa diperlukan sebuah metode diagnosa yang tepat untuk deteksi dini.

\section{METODE PENELITIAN}

Flowchart penelitian yang dilakukan adalah seperti ditunjukkan pada gambar 1 berikut:

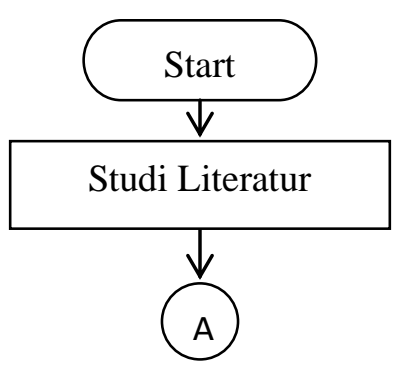




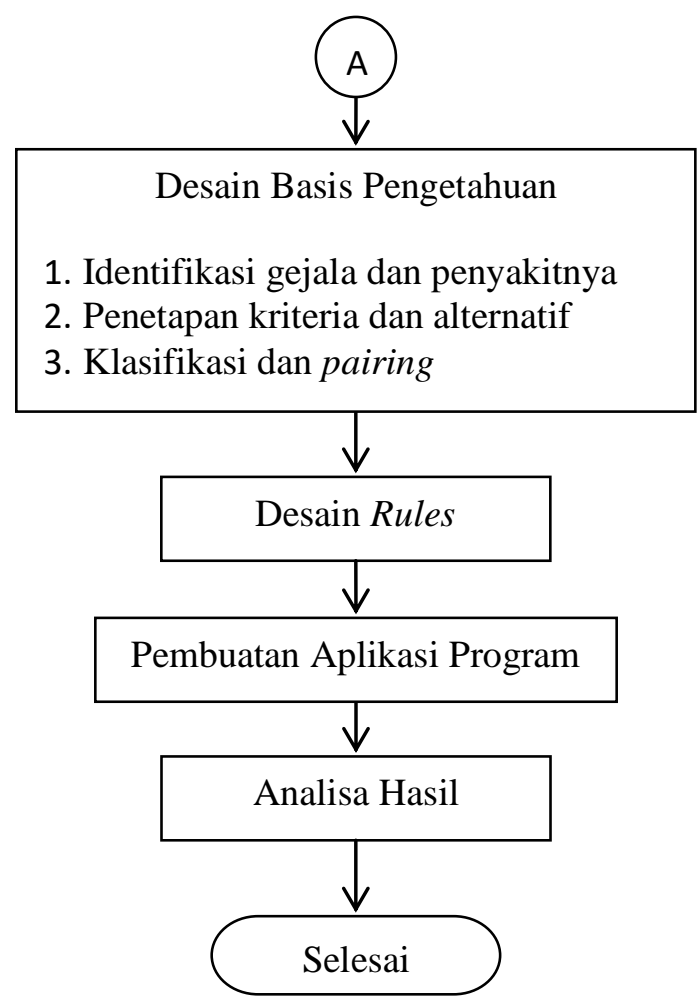

Gambar 1. Tahapan Penelitian

Secara garis besar penelitian ini dibagi menjadi dua tahap, yaitu: tahap desain basis pengetahuan dan tahap pembuatan aplikasi program. Tahap pembuatan basis pengetahuan terdiri dari dua langkah utama, yaitu tahap klasifikasi pengetahuan dan tahap desain rules. Tahapan klasifikasi pengetahuan adalah tahap identifikasi dan klasifikasi pengetahuan (yaitu berupa fakta dan data) yang dibutuhkan untuk memahami, memformulasikan dan memecahkan persoalan (Ifriza dan Djuniadi (2015). Tahapan klasifikasi pengetahuan pada penelitian ini adalah :

1. Identifikasi gejala dan penyakit yang biasa terjadi pada pasca Lebaran. Identifikasi dilakukan dengan metode penelusuran pada website - website kesehatan yang membahas topik "Penyakit pasca Lebaran".

2. Penetapan kriteria dan alternatif. Kriteria dan alternatif merupakan salah satu komponen utama pada perancangan SPK (Indraswari, dkk., 2015). Penetapan kriteria dilakukan setelah identifikasi tahap pertama selesai dilakukan. Data gejala penyakit menjadi komponen kriteria, sedangkan data penyakit adalah komponen alternatif.

3. Klasifikasi dan pairing penyakit dengan gejala-gejalanya.

Tahapan selanjutnya adalah tahap desain rules sebagai motor inferensi untuk ekstraksi pengetahuan yang disimpan untuk membuat kesimpulan diagnosa. Inferensi adalah bagian yang mengandung mekanisme fungsi berpikir dan pola-pola penalaran sistem yang digunakan oleh seorang pakar (Turban, 1995, dalam Yuwono, dkk., 2013). Desain rule dilakukan dengan menggunakan metode forward chaining dan disimpan dalam bentuk klausa IF-THEN. Forward Chaining merupakan suatu penalaran yang dimulai dari fakta untuk mendapatkan kesimpulan (conclusion) dari fakta tersebut (Yunus dan Setyowibowo, 2011). Penelusuran dilakukan dengan 
menggunakan rules yang premisnya cocok dengan fakta yang diketahui tersebut untuk memperoleh fakta baru dan melanjutkan proses hingga goal dicapai.

Tahapan berikutnya adalah tahap pembuatan program. Program SPK Diagnosa Penyakit ini dirancang dengan tujuan mudah digunakan oleh orang awam sekalipun. Dengan memperhatikan trend teknologi terkini, maka program dibangun dengan menggunakan tools App Inventor. Hasil akhir, program SPK diagnosa penyakit ini adalah aplikasi apk yang dapat di-install pada smartphone Android.

\section{HASIL DAN PEMBAHASAN}

Dengan berdasarkan pencarian pada artikel - artikel kesehatan dengan metode penelusuran website kesehatan di Indonesia, diperoleh hasil seperti yang ditunjukkan pada tabel 1.

Tabel 1. Identifikasi Gejala dan Penyakit pasca Lebaran

\begin{tabular}{|c|c|c|c|c|c|c|c|c|c|c|c|c|c|c|}
\hline No & Gejala penyakit & 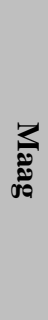 & 를. & 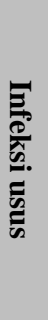 & 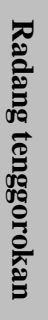 & 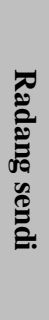 & $\frac{n}{\overline{0}}$ & 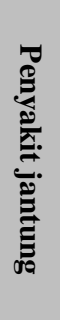 & 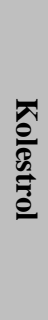 & 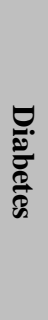 & 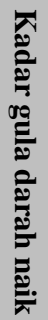 & 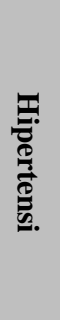 & 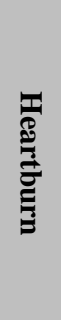 & 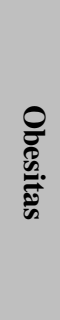 \\
\hline & & P1 & P2 & P3 & P4 & P5 & P6 & P7 & P8 & P9 & P10 & P11 & $\mathrm{P} 12$ & P13 \\
\hline 1 & $\begin{array}{l}\text { Rasa panas pada perut } \\
\text { bagian atas (G1) }\end{array}$ & $\mathrm{X}$ & & $x$ & & & & & & & & & & \\
\hline 2 & Mual (G2) & $x$ & & $x$ & & & & $x$ & & & & $x$ & & \\
\hline 3 & $\begin{array}{l}\text { Kembung pada perut bagian } \\
\text { atas (G3) }\end{array}$ & $\mathrm{x}$ & & & & & & & & & & & & \\
\hline 4 & $\begin{array}{l}\text { Refluks (kembalinya } \\
\text { makanan atau cairan dari } \\
\text { lambung ke kerongkongan) -- } \\
\text { (G4) }\end{array}$ & $\mathrm{X}$ & & & & & & & & & & & & \\
\hline 5 & Sering bersendawa (G5) & $x$ & & & & & & & & & & & & \\
\hline 6 & Muntah (G6) & $x$ & & & & & & & & & & & & \\
\hline 7 & $\begin{array}{l}\text { Nyeri ulu hati atau rasa } \\
\text { panas ketika atau setelah } \\
\text { makan (G7) }\end{array}$ & $\mathrm{x}$ & $\mathrm{x}$ & & & & & & & & & & & \\
\hline 8 & $\begin{array}{l}\text { Buang air besar encer dan } \\
\text { sering (G8) }\end{array}$ & & $x$ & & & & & & & & $\mathrm{x}$ & & & \\
\hline 9 & Nyeri perut (G9) & & $x$ & & & & & & & & & & & \\
\hline 10 & Demam (G10) & & $x$ & & & & & & & & & & & \\
\hline 11 & Darah dalam tinja (G11) & & $x$ & & & & & & & & & & & \\
\hline 12 & Kembung (G12) & & $x$ & & & & & & & & & & & \\
\hline 13 & Tidak nafsu makan (G13) & & & $x$ & & & & & & & & & & \\
\hline 14 & Sakit perut (G14) & & & $x$ & & & & & & & & & & \\
\hline 15 & Sembelit (G15) & & & $x$ & & & & & & & & & & \\
\hline 16 & Diare (G16) & & & $x$ & & & & & & & & & & \\
\hline 17 & $\begin{array}{l}\text { Sakit kepala sebelah } \\
\text { (migrain) -- (G17) }\end{array}$ & & & & $\mathrm{X}$ & & & & & & & & & \\
\hline 18 & Pembesaran kelenjar pada & & & & $\mathrm{X}$ & & & & & & & & & \\
\hline
\end{tabular}




\begin{tabular}{|c|c|c|c|c|c|c|c|c|c|c|c|c|c|c|}
\hline \multirow[t]{2}{*}{ No } & \multirow[t]{2}{*}{ Gejala penyakit } & $\underset{10}{20}$ & అ... & 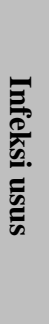 & 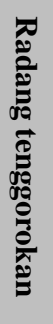 & 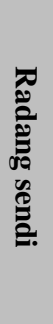 & 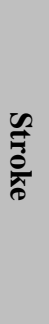 & 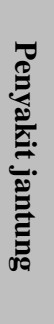 & 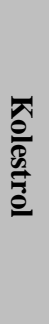 & 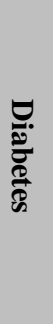 & 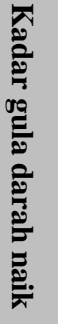 & 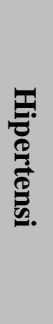 & 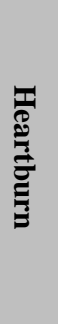 & 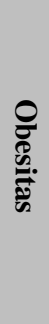 \\
\hline & & $\mathrm{P} 1$ & $\mathrm{P} 2$ & $\mathrm{P} 3$ & P4 & P5 & P6 & P7 & P8 & $\mathrm{P} 9$ & P10 & P11 & $\mathrm{P} 12$ & $\mathrm{P} 13$ \\
\hline & leher (G18) & & & & & & & & & & & & & \\
\hline 19 & $\begin{array}{l}\text { Tonsil/amandel yang } \\
\text { membengkak (G19) }\end{array}$ & & & & $x$ & & & & & & & & & \\
\hline 20 & Nyeri otot (G20) & & & & $\mathrm{X}$ & & & & & & & & & \\
\hline 21 & Batuk (G21) & & & & $x$ & & & & & & & & & \\
\hline 22 & Hidung beringus (G22) & & & & $x$ & & & & & & & & & \\
\hline 23 & Iritasi (G23) & & & & $x$ & & & & & & & & & \\
\hline 24 & Gatal di tenggorokan (G24) & & & & $x$ & & & & & & & & & \\
\hline 25 & Kemerahan (G25) & & & & & $\mathrm{X}$ & & & & & & & & \\
\hline 26 & Pembengkakan sendi (G26) & & & & & $\mathrm{X}$ & & & & & & & & \\
\hline 27 & Nyeri sendi (G27) & & & & & $\mathrm{X}$ & & & & & & & & \\
\hline 28 & Kekakuan sendi (G28) & & & & & $\mathrm{X}$ & & & & & & & & \\
\hline 29 & Kehilangan fungsi sendi (G29) & & & & & $\mathrm{X}$ & & & & & & & & \\
\hline 30 & $\begin{array}{l}\text { tidak mampu tersenyum } \\
\text { karena mulut atau mata } \\
\text { terkulai (G30) }\end{array}$ & & & & & & $\mathrm{X}$ & & & & & & & \\
\hline 31 & $\begin{array}{l}\text { lengannya terasa lemas atau } \\
\text { mati rasa (G31) }\end{array}$ & & & & & & $\mathrm{X}$ & & & & & & & \\
\hline 32 & $\begin{array}{l}\text { Ucapan tidak jelas atau kacau } \\
\text { (G32) }\end{array}$ & & & & & & $\mathrm{X}$ & & & & & & & \\
\hline 33 & Pusing (G33) & & & & & & & $\mathrm{X}$ & $\mathrm{X}$ & & & $\mathrm{X}$ & & \\
\hline 34 & Nyeri dada (angina) -- (G34) & & & & & & & $x$ & & & & $\mathrm{X}$ & & \\
\hline 35 & Keringat dingin (G35) & & & & & & & $\mathrm{X}$ & & & & & & \\
\hline 36 & Sesak napas (G36) & & & & & & & $\mathrm{X}$ & $\mathrm{X}$ & & & $\mathrm{X}$ & & $\mathrm{X}$ \\
\hline 37 & $\begin{array}{l}\text { Nyeri kepala bagian bawah } \\
\text { dekat tengkuk (G37) }\end{array}$ & & & & & & & & $\mathrm{X}$ & & & $\mathrm{X}$ & & \\
\hline 38 & $\begin{array}{l}\text { Penurunan atau kenaikan } \\
\text { berat badan yang drastis } \\
\text { (G38) }\end{array}$ & & & & & & & & $\mathrm{X}$ & & & & & \\
\hline 39 & $\begin{array}{l}\text { Nyeri betis bila berjalan } \\
\text { (G39) }\end{array}$ & & & & & & & & $\mathrm{X}$ & & & & & \\
\hline 40 & pandangan kabur (G40) & & & & & & & & & $x$ & & & & \\
\hline 41 & $\begin{array}{l}\text { Perubahan keadaan kulit } \\
\text { (G41) }\end{array}$ & & & & & & & & & $x$ & & & & \\
\hline 42 & $\begin{array}{l}\text { rentan terhadap infeksi atau } \\
\text { penyakit (G42) }\end{array}$ & & & & & & & & & $x$ & & & & \\
\hline 43 & $\begin{array}{l}\text { lambatnya penyembuhan } \\
\text { luka (G43) }\end{array}$ & & & & & & & & & $x$ & & & & \\
\hline 44 & sering haus (G44) & & & & & & & & & & $x$ & & $x$ & \\
\hline 45 & rasa ingin makan terus (G45) & & & & & & & & & & $X$ & & $\mathrm{X}$ & \\
\hline 46 & Penglihatan buram (G46) & & & & & & & & & & & $x$ & & \\
\hline
\end{tabular}




\begin{tabular}{|c|c|c|c|c|c|c|c|c|c|c|c|c|c|c|}
\hline No & Gejala penyakit & 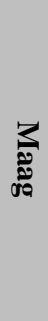 & & 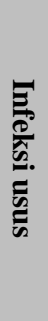 & 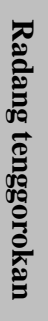 & 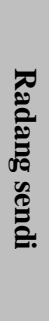 & $\frac{\mathscr{0}}{\frac{0}{3}}$ & 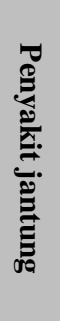 & 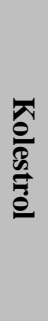 & 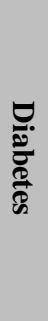 & 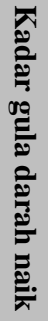 & 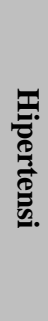 & 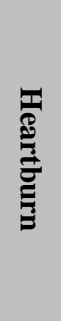 & $\begin{array}{l}\stackrel{0}{\circ} \\
\stackrel{0}{*} \\
\stackrel{0}{*}\end{array}$ \\
\hline & & P1 & $\mathrm{P} 2$ & P3 & P4 & P5 & P6 & $\mathrm{P} 7$ & P8 & P9 & P10 & P11 & P12 & P13 \\
\hline 47 & Telinga berdenging (G47) & & & & & & & & & & & $\mathrm{x}$ & & \\
\hline 48 & Kebingungan (G48) & & & & & & & & & & & $x$ & & \\
\hline 49 & $\begin{array}{l}\text { Detak jantung tak teratur } \\
\text { (G49) }\end{array}$ & & & & & & & & & & & $\mathrm{X}$ & & \\
\hline 50 & Kelelahan (G50) & & & & & & & & & & & $\mathrm{x}$ & & \\
\hline 51 & Darah dalam urin (G51) & & & & & & & & & & & $x$ & & $x$ \\
\hline 52 & $\begin{array}{l}\text { Sensasi berdetak di dada, } \\
\text { leher, atau telinga (G52) }\end{array}$ & & & & & & & & & & & $\mathrm{X}$ & & \\
\hline 53 & Sakit Lutut (G53) & & & & & & & & & & & & & $x$ \\
\hline 54 & Sakit Punggung (G54) & & & & & & & & & & & & & $\mathrm{X}$ \\
\hline 55 & Varises (G55) & & & & & & & & & & & & & $x$ \\
\hline 56 & Tekanan Darah Tinggi (G56) & & & & & & & & & & & & & $x$ \\
\hline 57 & Mendengkur (G57) & & & & & & & & & & & & & $x$ \\
\hline
\end{tabular}

Setelah terbentuk data gejala dan kemungkinan penyakit yang terjadi, maka data hasil identifikasi tersebut dirubah menjadi data kriteria dan alternatif penyusun SPK, seperti yang diperlihatkan pada tabel 2.

Tabel 2. Data Kriteria dan Alternatif komponen SPK

\begin{tabular}{|c|c|c|}
\hline No & $\begin{array}{c}\text { Kode Kriteria } \\
\text { (Gejala Penyakit yang } \\
\text { dirasakan) }\end{array}$ & $\begin{array}{c}\text { Kode } \\
\text { Alternatif } \\
\text { (Penyakit) }\end{array}$ \\
\hline \multirow[t]{7}{*}{1} & G1 & P1 \\
\hline & $\mathrm{G} 2$ & \\
\hline & G3 & \\
\hline & G4 & \\
\hline & G5 & \\
\hline & G6 & \\
\hline & G7 & \\
\hline \multirow[t]{6}{*}{2} & G7 & P2 \\
\hline & G8 & \\
\hline & G9 & \\
\hline & G10 & \\
\hline & G11 & \\
\hline & G12 & \\
\hline \multirow[t]{4}{*}{3} & G13 & P3 \\
\hline & G14 & \\
\hline & G15 & \\
\hline & G16 & \\
\hline
\end{tabular}




\begin{tabular}{|c|c|c|}
\hline No & $\begin{array}{c}\text { Kode Kriteria } \\
\text { (Gejala Penyakit yang } \\
\text { dirasakan) }\end{array}$ & $\begin{array}{c}\text { Kode } \\
\text { Alternatif } \\
\text { (Penyakit) } \\
\end{array}$ \\
\hline \multirow[t]{8}{*}{4} & G17 & P4 \\
\hline & G18 & \\
\hline & G19 & \\
\hline & $\mathrm{G} 20$ & \\
\hline & G21 & \\
\hline & $\mathrm{G} 22$ & \\
\hline & $\mathrm{G} 23$ & \\
\hline & G24 & \\
\hline \multirow[t]{5}{*}{5} & G25 & P5 \\
\hline & G26 & \\
\hline & $\mathrm{G} 27$ & \\
\hline & $\mathrm{G} 28$ & \\
\hline & G29 & \\
\hline \multirow[t]{3}{*}{6} & G30 & P6 \\
\hline & G31 & \\
\hline & G32 & \\
\hline \multirow[t]{5}{*}{7} & $\mathrm{G} 2$ & P7 \\
\hline & G33 & \\
\hline & G34 & \\
\hline & G35 & \\
\hline & G36 & \\
\hline \multirow[t]{5}{*}{8} & G33 & P8 \\
\hline & G36 & \\
\hline & G37 & \\
\hline & G38 & \\
\hline & G39 & \\
\hline \multirow[t]{4}{*}{9} & G40 & P9 \\
\hline & G41 & \\
\hline & G42 & \\
\hline & $\mathrm{G} 43$ & \\
\hline \multirow[t]{3}{*}{10} & G8 & P10 \\
\hline & G44 & \\
\hline & G45 & \\
\hline \multirow[t]{8}{*}{11} & G2 & P11 \\
\hline & G33 & \\
\hline & G34 & \\
\hline & G36 & \\
\hline & G37 & \\
\hline & G46 & \\
\hline & G47 & \\
\hline & G48 & \\
\hline
\end{tabular}

Vol. 6- No. 2; Mei 2018 


\begin{tabular}{|c|c|c|}
\hline No & $\begin{array}{c}\text { Kode Kriteria } \\
\text { (Gejala Penyakit yang } \\
\text { dirasakan) }\end{array}$ & $\begin{array}{c}\text { Kode } \\
\text { Alternatif } \\
\text { (Penyakit) }\end{array}$ \\
\hline & G49 & \\
\hline & G50 & \\
\hline & G51 & \\
\hline & G52 & \\
\hline \multirow[t]{2}{*}{12} & G44 & P12 \\
\hline & G45 & \\
\hline \multirow[t]{7}{*}{13} & G36 & P13 \\
\hline & G51 & \\
\hline & G53 & \\
\hline & G54 & \\
\hline & G55 & \\
\hline & G56 & \\
\hline & G57 & \\
\hline
\end{tabular}

Setelah komponen kriteria dan alternatif terbentuk, maka langkah selanjutnya adalah desain rules yang dilakukan dengan metode forward chaining. Desain rules diperlihatkan pada gambar 2 .

Berdasarkan desain rules seperti yang ditunjukkan pada Gambar 2, kemudian dihubungkan dengan operator logika IF-THEN, sehingga dihasilkan 13 klausa rules. Tabel 3 memperlihatkan klausa rules untuk melakukan diagnosa penyakit pasca hari lebaran.

Tabel 3. Klausa Rules IF-THEN

\begin{tabular}{|c|c|}
\hline Rule & Klausa Rules IF-THEN \\
\hline 1 & If $\mathrm{G} 1 \wedge \mathrm{G} 2 \wedge \mathrm{G} 3 \wedge \mathrm{G} 4 \wedge \mathrm{G} 5 \wedge \mathrm{G} 6 \wedge \mathrm{G} 7 \rightarrow \mathrm{P} 1$ \\
\hline 2 & If $\mathrm{G} 1 \wedge \mathrm{G} 2 \wedge \neg \mathrm{G} 3 \wedge \mathrm{G} 13 \wedge \mathrm{G} 14 \wedge \mathrm{G} 15 \wedge \mathrm{G} 16 \rightarrow \mathrm{P} 3$ \\
\hline 3 & If $\neg \mathrm{G} 1 \wedge \mathrm{G} 2 \wedge \mathrm{G} 33 \wedge \mathrm{G} 34 \wedge \mathrm{G} 35 \wedge \mathrm{G} 36 \rightarrow \mathrm{P} 7$ \\
\hline 4 & If $\neg \mathrm{G} 1 \wedge \mathrm{G} 2 \wedge \mathrm{G} 33 \wedge \neg \mathrm{G} 34 \wedge \mathrm{G} 36 \wedge \mathrm{G} 37 \wedge \mathrm{G} 38 \wedge \mathrm{G} 39 \rightarrow \mathrm{P} 8$ \\
\hline 5 & $\begin{array}{l}\text { If } \neg \mathrm{G} 1 \wedge \mathrm{G} 2 \wedge \mathrm{G} 33 \wedge \neg \mathrm{G} 34 \wedge \neg \mathrm{G} 36 \wedge \mathrm{G} 37 \wedge \mathrm{G} 46 \wedge \mathrm{G} 47 \wedge \mathrm{G} 48 \wedge \mathrm{G} 49 \wedge \mathrm{G} 50 \\
\wedge \mathrm{G} 51 \wedge \mathrm{G} 52 \rightarrow \mathrm{P} 11\end{array}$ \\
\hline 6 & If $\neg \mathrm{G} 1 \wedge \neg \mathrm{G} 2 \wedge \mathrm{G} 7 \wedge \mathrm{G} 8 \wedge \mathrm{G} 9 \wedge \mathrm{G} 10 \wedge \mathrm{G} 11 \wedge \mathrm{G} 12 \rightarrow \mathrm{P} 2$ \\
\hline 7 & If $\neg \mathrm{G} 1 \wedge \neg \mathrm{G} 2 \wedge \neg \mathrm{G} 7 \wedge \mathrm{G} 8 \wedge \mathrm{G} 44 \wedge \mathrm{G} 45 \rightarrow \mathrm{P} 10$ \\
\hline 8 & $\begin{array}{l}\text { If } \neg \mathrm{G} 1 \wedge \neg \mathrm{G} 2 \wedge \neg \mathrm{G} 7 \wedge \neg \mathrm{G} 8 \wedge \mathrm{G} 17 \wedge \mathrm{G} 18 \wedge \mathrm{G} 19 \wedge \mathrm{G} 20 \wedge \mathrm{G} 21 \wedge \mathrm{G} 22 \wedge \mathrm{G} 23 \wedge \\
\mathrm{G} 24 \rightarrow \mathrm{P} 4\end{array}$ \\
\hline 9 & If $\neg \mathrm{G} 1 \wedge \neg \mathrm{G} 2 \wedge \neg \mathrm{G} 7 \wedge \neg \mathrm{G} 8 \wedge \neg \mathrm{G} 17 \wedge \mathrm{G} 25 \wedge \mathrm{G} 26 \wedge \mathrm{G} 27 \wedge \mathrm{G} 28 \wedge \mathrm{G} 29 \rightarrow \mathrm{P} 5$ \\
\hline 10 & If $\neg \mathrm{G} 1 \wedge \neg \mathrm{G} 2 \wedge \neg \mathrm{G} 7 \wedge \neg \mathrm{G} 8 \wedge \neg \mathrm{G} 17 \wedge \neg \mathrm{G} 25 \wedge \mathrm{G} 30 \wedge \mathrm{G} 31 \wedge \mathrm{G} 32 \rightarrow \mathrm{P} 6$ \\
\hline 11 & If $\neg \mathrm{G} 1 \wedge \neg \mathrm{G} 2 \wedge \neg \mathrm{G} 7 \wedge \neg \mathrm{G} 8 \wedge \neg \mathrm{G} 17 \wedge \neg \mathrm{G} 25 \wedge \neg \mathrm{G} 30 \wedge \mathrm{G} 44 \wedge \mathrm{G} 45 \rightarrow \mathrm{P} 12$ \\
\hline 12 & $\begin{array}{l}\text { If } \neg \mathrm{G} 1 \wedge \neg \mathrm{G} 2 \wedge \neg \mathrm{G} 7 \wedge \neg \mathrm{G} 8 \wedge \neg \mathrm{G} 17 \wedge \neg \mathrm{G} 25 \wedge \neg \mathrm{G} 30 \wedge \mathrm{G} 36 \wedge \mathrm{G} 51 \wedge \mathrm{G} 52 \wedge \\
\mathrm{G} 53 \wedge \mathrm{G} 54 \wedge \mathrm{G} 55 \wedge \mathrm{G} 56 \wedge \mathrm{G} 57 \rightarrow \mathrm{P} 13\end{array}$ \\
\hline 13 & $\begin{array}{l}\text { If } \neg \mathrm{G} 1 \wedge \neg \mathrm{G} 2 \wedge \neg \mathrm{G} 7 \wedge \neg \mathrm{G} 8 \wedge \neg \mathrm{G} 17 \wedge \neg \mathrm{G} 25 \wedge \neg \mathrm{G} 30 \wedge \mathrm{G} 40 \wedge \mathrm{G} 41 \wedge \mathrm{G} 42 \wedge \\
\mathrm{G} 43 \rightarrow \mathrm{P} 9\end{array}$ \\
\hline
\end{tabular}




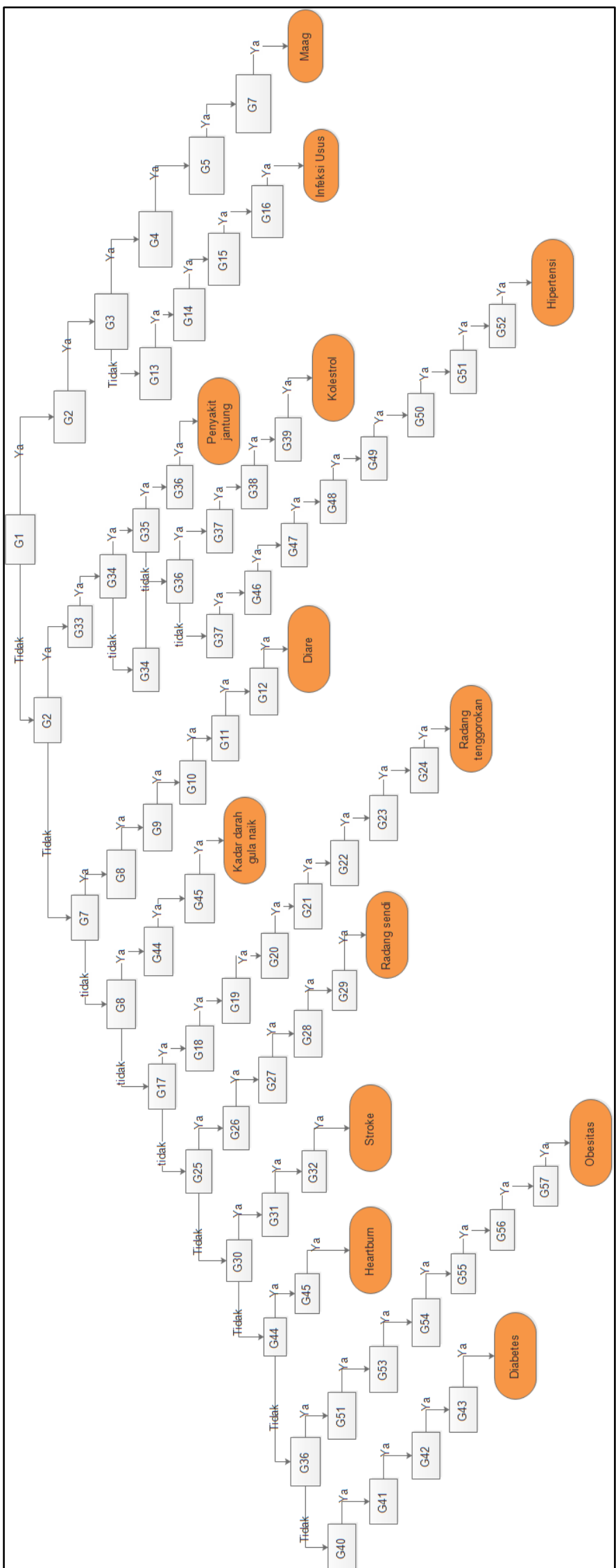

Vol. 6-No. 2; Mei 2018 
Gambar 2. Desain rules SPK dengan metode forward chaining

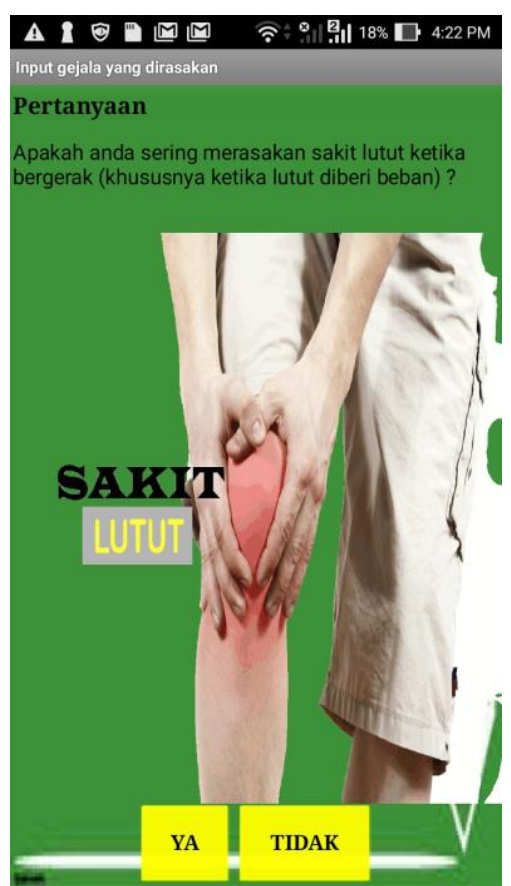

Gambar 3. User Interface input data gejala penyakit

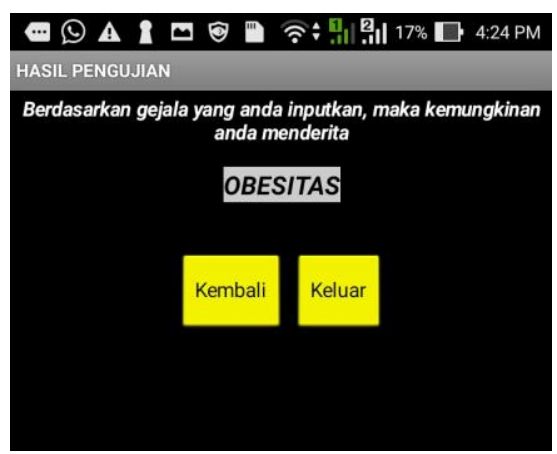

Gambar 4. User Interface kesimpulan

Gambar 3 dan gambar 4 memperlihatkan user interface program aplikasi yang menjadi output penelitian ini. Gambar 3 adalah tampilan antarmuka ketika user menginputkan gejala-gejala yang dirasakan. Kemudian, setelah diolah oleh rules, program menampilkan hasil pengujian, seperti yang ditampilkan oleh gambar 4 .

Ujicoba dilakukan kepada 30 orang yang diminta untuk menginstall dan menggunakan aplikasi Diagnosa Penyakit pasca Lebaran ini. Ujicoba dilakukan untuk mengetahui fungsional dari seluruh fitur yang terdapat pada aplikasi. Selain itu juga untuk mengetahui apakah rules yang dibangun telah mampu menghasilkan kesimpulan yang sesuai berdasarkan input dari user. Dari hasil ujicoba, seluruh user merasa nyaman dalam menggunakan aplikasi. User mudah dalam mengikuti instruksi dan juga menginputkan gejala-gejala yang dirasakan. User juga merasa terbantu dalam melakukan diagnosa dini penyakit yang mungkin terjadi. Aplikasi program mampu menampilkan output berupa kesimpulan yang sesuai berdasarkan input user yang diberikan. Berdasarkan hasil ujicoba dapat disimpulkan bahwa user 
dapat melakukan self diagnosis dengan memanfaatkan aplikasi Diagnosa Dini Penyakit pasca Lebaran.

\section{KESIMPULAN}

Berdasarkan penelitian yang telah dilakukan dapat diambil beberapa kesimpulan sebagai berikut :

1. Berdasarkan hasil analisis, perancangan dan hasil ujicoba yang telah dilakukan, mekanisme inferensi forward chaining dan rules yang dibangun telah mampu menghasilkan kesimpulan yang sesuai berdasarkan input dari user.

2. Berdasarkan hasil analisis, perancangan dan hasil ujicoba yang telah dilakukan maka Sistem Pendukung Keputusan yang dibangun telah berhasil membantu user melakukan self diagnosis terhadap gejala penyakit yang mungkin diderita pada pasca lebaran.

\section{SARAN}

Program dapat dikembangkan menjadi lebih akurat dengan ditambahkan basis pengetahuan kepakaran yang lebih baik. Dapat pula ditambahkan mekanisme learning agar program mampu belajar dan self update basis pengetahuan yang dimiliki.

\section{DAFTAR PUSTAKA}

Fitriani, E., 2012, Pola Kebiasaan Makan Orang Lanjut Usia, Humanus, Vol. 11, No. 2, 134 - 144, http://ejournal.unp.ac.id/index.php/humanus/article/view/ 2162/1807

Ifriza, N, I., dan Djuniadi, 2015, Perancangan Sistem Pakar Penyuluh Diagnosa Hama Padi dengan Metode Forward Chaining, Jurnal Teknik Elektro, Vol. 7, No. 1, https://journal.unnes.ac.id/artikel_nju/jte/8590

Indraswari, D.P., Soebroto, A.A., dan Marhaendraputro, E.A., 2015, Sistem Pendukung Keputusan Deteksi Dini Penyakit Stroke Menggunakan Metode Dempster-Shafer, Journal of Enviromental Engineering and Sustainable Technology, Vol. 02, No. 02, Page 97-104, http://jeest.ub.ac.id/index.php/jeest/article/view/37

Januwati, E., 2016, Jaga Pola Makan, Waspada Penyakit Pasca-Lebaran, http://lifestyle.bisnis.com/read/20160707/106/564231/jaga-pola-makanwaspada-penyakit-pasca-lebaran

Sofiana, S., 2016, Lebaran, Penyakit akibat Pola Makan Dominan di RSUD Dr Soetomo, Angka Kecelakaan dan Mercon Minim, http://surabaya.tribunnews.com/2016/07/07/lebaran-penyakit-akibat-polamakan-dominandi-rsud-dr-soetomo-angka-kecelakaan-dan-mercon-minim.

Tariq, A., and Rafi, K., 2012, Intelligent Decision Support Systems-A Framework, Information and Knowledge Management, Vol. 2, No. 6, Page 12-20, http://www.iiste.org/Journals/index.php/IKM/article/view/2492 
Wahyudi, A. T., Pradana, Y., dan Saputro, O., 2017, Sistem Pendukung Keputusan Kelompok dalam Penentuan Lokasi Obyek Wisata Terbaik di Lombok, Tekinfo | Scientific Journal of Industrial and Information Engineering, Vol. 06, Issue. $01, \quad$ Pp. 62-76, http://ejurnal.setiabudi.ac.id/ojs/index.php/tekinfo/article/view/317

Yunus, M., dan Setyowibowo, S., 2011, Aplikasi Sistem Pendukung Keputusan Diagnosa Penyakit Paru-Paru Dengan Metode Forward Chaining, Jurnal Teknologi Informasi, Vol. 2, No. 2, http://ejurnal.stimata.ac.id/index.php/TI/ article/view/130

Yuwono, B., Wibowo, A., dan Prasetyo, D.B., 2013, Sistem Pakar Berbasis Web Untuk Diagnosa Hama Dan Penyakit Pada Tanaman Melon, in: Seminar Nasional Informatika 2013, UPN "Veteran" Yogyakarta, Yogyakarta, pp. 84-89. 